\title{
Tanggung Jawab Notaris Atas Akta yang Tidak Dibacakan Dihadapan Para Penghadap
}

\author{
I Wayan Arya Kurniawan ${ }^{1}$
}

1Program Studi Magister (S2) Kenotariatan Fakultas Hukum Universitas Udayana, BaliIndonesia, E-mail: aryakurniawan@live.com

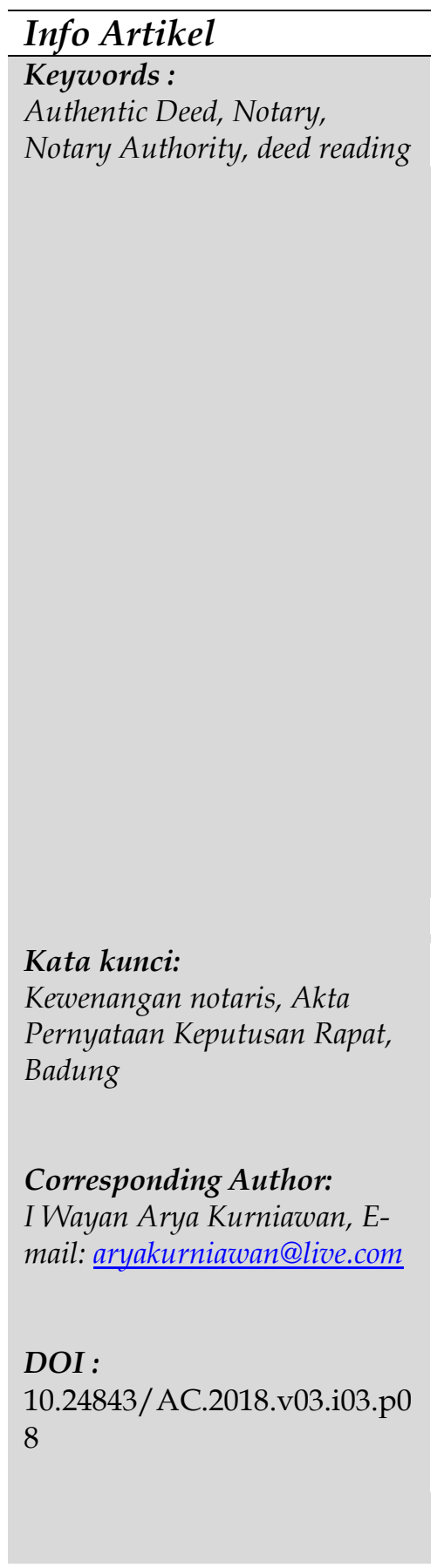

\begin{abstract}
Notary has an obligation to ensure what is contained in the notary deed is truly understood and in accordance with the wishes of the parties. The Notary's obligation to read the deed and write down the conditions of the parties appeared before the Notary and the reason that caused the deed is not read on the closing section of the deed is the order of the Law. If there is an error in the parties' understanding of the deed and causes uncertainty over the deed made, then the power and usefulness of the notary deed is questionable, including the responsibility of the Notary who deliberately doesn't read the deed before the parties. The purpose of writing this journal is to know, describe, and analyze the position of the notary deed which is not read by the notary before the parties. The research method used is empirical research method with case approach, analytical approach, and legal approach. The results of the study showed that the reading of the deed is a must in every authentic deed drawing as part of the formality of the deed. Notaries are considered responsible and can be blamed if there is a misunderstanding regarding the purpose and content of the deed resulted inevasion of the deed. A notary who intentionally does not read the deed made before the parties is considered to violate the law that can result in the deed drawn being void ab initio and its enforceability becomes similar to a privately made deed.
\end{abstract}

Abstrak
Notaris mempunyai kewajiban untuk memastikan bahwa apa
yang termuat dalam akta notaris sungguh-sungguh telah
dimengerti dan sesuai dengan kehendak para pihak. Kewajiban
Notaris membacakan akta dan menuliskan keterangan keadaan
penghadap saat menghadap kepada Notaris serta alasan atau
keterangan akta tidak dibacakan dalam penutup akta adalah
perintah Undang-Undang. Apabila ketika terjadi kesalahan
pemahaman para pihak atas akta tersebut dan menyebabkan
ketidakjelasan atas akta yang dibuat, maka kekuatan dan
kegunaan akta notaris tersebut patut dipertanyakan dan juga
termasuk tanggung jawab dari Notaris yang secara sengaja tidak
membacakan akta dihadapan para pihak. Tujuan penulisan
jurnal ini adalah untuk mengetahui, mendeskripsikan, dan
menganalisa kedudukan akta notaris yang tidak dibacakan oleh
notaris dihadapan para penghadap. Adapun metode yang
dipergunakan adalah metode penelitian empiris dengan
pendekatan kasus, pendekatan analisis, dan pendekatan


perundang - undangan. Hasil penelitian yang diperoleh bahwa Pembacaan akta merupakan suatu kewajiban untuk pembuatan akta otentik sebagai bentuk peresmian akta. Notaris dianggap bertanggungjawab dan dapat dipersalahkan apabila terdapat kesalahpahaman mengenai maksud dan isi dari akta dan mengakibatkan terjadi wanprestasi atas akta tersebut. Notaris yang secara sengaja tidak membacakan akta yang dibuat dihadapan para penghadap tersebut merupakan suatu pelanggaran yang berakibat kepada akta yang dibuatnya tersebut menjadi batal demi hukum dan kekuatan pembuktiannya menjadi sebuah akta dibawah tangan.

\section{Pendahuluan}

Notaris merupakan salah satu pejabat umum yang memiliki suatu wewenang untuk membuat akta otentik, yang mana wewenang tersebut berasal dari peraturan perundang - undangan yang berlaku. ${ }^{1}$ Pengangkatan dan pemberhentian jabatan notaris dilakukan berdasarkan suatu kekuasaan umum yang dimiliki oleh Menteri. Notaris bertugas memberikan pelayanan jasa terkait pembuatan akta otentik sebagai suatu alat bukti tertulis bagi setiap masyarakat yang membutuhkannya. Dengan adanya notaris ini sebagai bentuk penerapan hukum pembuktian. ${ }^{2}$

Undang - Undang Nomor 2 tahun 2014 tentang perubahan atas Undang-Undang Nomor 30 Tahun 2004 Tentang Jabatan Notaris (UUJN-Perubahan) merupakan ketentuan yang mengatur jabatan notaris. Ketentuan Pasal 1 ayat (1) pada peraturan itu menentukan bahwa notaris sebagai pejabat umum berwenang untuk membentuk suatu akta otentik dan wewenang lainnya yang juga ditentukan pada peraturan tersebut. Sedangkan dalam Kitab Undang - Undang Hukum Perdata mengatur bahwa akta otentik adalah suatu akta yang dibentuk sesuai dengan ketentuan undang undang dihadapan atau oleh pejabat umum yang memiliki kewenangan sesuai tempat akta itu dibentuk. Hal ini merupakan bentuk pelaksanaan pasal 1868 KUHPer tersebut, menurut Lumban Tobing yang dikutip oleh Sjaifurrachman merupakan peraturan yang mendasari pemberlakuan ketentuan tentang jabatan notaris, sehingga yang dimaksud pejabat umum adalah notaries tersebut. ${ }^{3}$

Maka dari itu, notaris merupakan pejabat umum yang diberikan wewenang untuk membuat akta otentik sesuai dengan peraturan yang berlaku agar dapat memberikan suatu perlindungan hukum dan kepastian hukum bagi para pihak. Pembentukan akta otentik yang dilakukan di notaris tidak hanya berdasarkan oleh undang - undang, tetapi merupakan kehendak dari pihak - pihak yang bersangkutan agar ada suatu kepastian dari hak dan kewajiban mereka. Sehingga dari hal tersebut menciptakan suatu bentuk kepastian hukum dan perlindungan hukum bagi pihak-pihak yang

${ }^{1}$ Lestari, A.D. (2014). Kekuatan Alat Bukti Akta Otentik Yang Dibuat Oleh Notaris Dalam Pembuktian Perkara Perdata Di Pengadilan Negeri Sleman. Jurnal Ilmu Hukum,1-19. h. 11

2 Budiono, Herlien. (2013). Kumpulan Tulisan Hukum Perdata di Bidang Kenotariatan. Bandung : Citra Aditya Bakti, h 220.

${ }^{3}$ Sjaifurrachman. (2011). Aspek Pertanggungjawaban Notaris dalam Pembuatan Akta. Bandung: Mandar Maju. h. 62. 
bersangkutan maupun pihak lain yang berkaitan dengan hal tersebut. Kebenaran yang terdapat pada akta tersebut merupakan kebenaran formal yang diketahui oleh notaris dari pemberitahuan para pihak yang bersangkutan.

Notaris memberikan perlindungan hukum kepada masyarakat terkait pengesahan (legalisasi) dari setiap perbuatan atau transaksi - transaksi yang diperbuat oleh masyarakat. ${ }^{4}$ Dalam pembuatan akta otentik, notaris wajib memuat kehendak para pihak serta tidak melanggar norma - norma yang ada di masyarakat maupun norma hukum, dan akta tersebut harus dimengerti dengan jelas oleh kedua belah pihak. Notaris wajib membacakan isi akta agar para pihak jelas terhadap isi akta dan segala informasi terkait akta tersebut juga diketahui para pihak. Sehingga keputusan untuk setuju atau tidak setuju terhadap isi akta otentik tersebut ditentukan oleh para pihak yang nantinya akan menandatanganinya.

Dalam pelaksanaannya, kewajiban dan tugas notaris tersebut telah ditentukan oleh peraturan yang berlaku. Pelaksanaan kewajiban notaris dalam pembuatan akta otentik dalam jabatannya ditentukan dalam pasal 16 UUJN-Perubahan. Pembacaan akta yang dibuat notaris merupakan salah satu benruk dari kewajiban notaris, pembacaan akta tersebut harus dilakukan dihadapan para penghadap dan telah dihadiri oleh paling sedikit 2 orang saksi. Dalam pembuatan akta wasiat dibawah tangan, saksi yang diperlukan adalah 4 orang saksi dan penandatanganannya dilakukan pada saat itu juga oleh penghadap, saksi dan Notaris. Adapun Sanksi yang diterima oleh notaris yang tidak membacakan akta yang dibuatnya tersebut ditentukan dalam pasal 16 ayat (9) UUJN-Perubahan, yang mengakibatkan akta notaris tidak memiliki kekuatan hukum sebagai akta otentik dan hanya sebatas akta dibawah tangan.

Pada peraturan sebelumnya, Pelanggaran yang dilakukan notaris dengan tidak membacakan akta yang dibuatnya akan membuat akta tersebut memiliki kekuatan pembuktian sebagai akta dibawah tangan, bahkan batal demi hukum dan berdasarkan hal tersebut dapat digunakan sebagai dasar bagi pihak yang mengalami kerugian untuk meminta ganti rugi kepada notaris, sebagaimana ditentukan dalam pasal 84 Undang - Undang Nomor 30 Tahun 2004 tentang Jabatan Notaris. Akan tetapi, berdasarkan peraturan UUJN-Perubahan yang baru menyatakan bahwa peraturan peraturan yang sebelumya sudah tidak berlaku lagi.

Pada penerapan di lapangam (Das sein), saat ini banyak notaris yang tidak membacakan akta yang dibuatnya namun pada akhir akta disebutkan bahwa akta tersebut telah dibacakan oleh notaris. Hal ini yang sebenarnya mengakibatkan permasalahan dan menyebabkan akta yang dibuat oleh notaris tersebut menjadi akta dibawah tangan dan merugikan para pihak. Notaris dengan sengaja berbohong dan secara tidak langsung telah melakukan pemalsuan akta yang dibbuatnya tersebut. ${ }^{5}$ Dalam menjalankan tugasnya sebagai seorang pejabat umum yang memiliki wewenang membuat akta otentik, tidak menutup kemungkinan bagi notaris melakukan kesalahan yang berkaitan dengan profesionalitas kerjanya sebagaimana

\footnotetext{
${ }^{4}$ Darusman, Y. M. (2017). Kedudukan notaris sebagai pejabat pembuat akta otentik dan sebagai pejabat pembuat akta tanah. ADIL: Journal of Law, 7(1), 36-56. h.40

${ }^{5}$ Kie, Tan Thong. (2007). Studi Notariat \& Serba-serbi Praktek Notaris. Jakarta : Ichtiar Baru Van Hoeve. h. 634
} 
ditentukan dalam pasal 16 ayat (1) dan ayat (7) UUJN-Perubahan. Kesalahan kesalahan yang mungkin dilakukan notaris tersebut dapat menimbulkan penafsiran yang salah dari isi akta tersebut dan dapat mengakibatkan adanya wanprestasi baik dilakukan oleh salah satu pihak maupun para pihak yang bersangkutan, sehingga akta tidak akan bisa digunakan sebagaimana peruntukannya tersebut.

Hasil studi yang membahas mengenai pembacaan akta ini juga dibuat oleh Erlinda Saktiani Karwelo pada tahun 2014 yang membahas tentang pembacaan dan penandatanganan akta yang dilakukan oleh notaris melalui video conference ${ }^{6}$. Pembahasan serupa juga dibuat oleh Valentine Phebe Mowoka pada tahun 2014. ${ }^{7}$ Pada intinya membahas tanggung jawab notaris terhadap akta yang dibuatnya tersebut harus sesuai dengan peraturan yang berkaitan dengan pembuatan akta otentik tersebut, apabila akta yang dibuat tidak sesuai prosedur dan tata cara pembuatan akta otentik maka akta tersebut hanya akan berlaku sebagai akta dibawah tangan. Sedangkan untuk pembahasan dalam jurnal ini memfokuskan pada tanggung jawab notaris terhadap akta otentik yang tidak dibacakan dan kedudukan dari akta otentik yang tidak dibacakan oleh notaris.

Adapun permasalahan dalam penulisan jurnal ini adalah tanggung jawab notaris dan kedudukan akta notaris tersebut yang tidak dibacakan oleh notaris.

Penulisan jurnal ini bertujuan untuk mengetahui, mendeskripsikan, dan menganalisa tanggung jawab dan kedudukan akta notaris yang tidak dibacakan oleh notaris dihadapan para penghadap.

\section{Metode Penelitian}

Metode penelitian yang digunakan dalam penulisan jurnal ini yaitu metode penelitian empiris yaitu penelitian dengan meneliti tentang data-data sekunder yang telah di himpun dan dilanjutkan dengan meneliti data-data primer di lapangan. ${ }^{8}$ Penelitian ini untuk melihat kesenjangan dari peraturan hukum yang ada dengan kenyataan yang ada di masyarakat. Jenis pendekatan yang digunakan adalah pendekatan kasus, pendekatan analisis fakta, dan pendekatan sosiologis. Adapun sumber data yang digunakan adalah data primer dan data sekunder. Data primer merupakan data yang bersumber dari sumber asalnya yang belum pernah diuraikan dan diolah orang lain. Data - data tersebut merupakan data yang diperoleh dari penelitian yang dilakukan di lapangan. Sedangkan untuk data sekunder merupakan data pelengkap untuk menunjang penelitian yang dilakukan tersebut. Data - data sekunder tersebut merupakan data - data yang bersumber dari penelitian kepustakaan. Sedangkan untuk penggunaan Teknik pengumpulan data dalam penulisan jurnal ini yaitu dengan mengumpulkan data primer atau data lapangan dengan wawancara yang dilakukan di kantor notaris, dan untuk pengumpulan data - data sekunder yang digunakan adalah dengan menggunakan teknik membaca dan mencari buku - buku atau literatur yang

\footnotetext{
${ }^{6}$ Karwelo, E. S. (2014). Prospek Pembacaan dan Penandatanganan Akta Notaris Melalui Video Conference. Kumpulan Jurnal Mahasiswa Fakultas Hukum, 1(1).

${ }^{7}$ Mowoka, V. P. (2014). Pelaksanaan Tanggung Jawab Notaris terhadap Akta yang Dibuatnya. LEX ET SOCIETATIS, 2(4).

8 Soekanto, Soerjono. (2012). Pengantar Penelitian Hukum. Jakarta :UI Press. h.52
} 
sesuai dengan pembahasan dalam jurnal ini Sedangkan untuk metode analisa data menggunakan teknik analisis data kualitatif untuk menjawab permasalahan yang diangkat, dan disajika secara deskriptif kualitatif pada jurnal ini.

\section{Hasil dan Pembahasan}

\subsection{Tanggung Jawab Notaris Membacakan Akta yang Dibuat}

Terkait tanggung jawab dari notaris yang tidak membacakan akta yang dibuatnya secara langsung, sebelumnya harus dipahami terlebih dahulu kewenangan, kewajiban, dan larangan yang dimiliki oleh notaris dalam menjalankan jabatannya. Kewenangan notaris tersebut merupakan kewenangan atribusi yang berasal dari Undang-undang yang mengatur tentang jabatan notaris dalam membuat akta otentik dari objek yang diperjanjikan dalam akta tersebut sesuai dengan wilayah kerja dari notaris yang bersangkutan, termasuk pula membacakan dan menandatangani akta yang dibuat tersebut. ${ }^{9}$

Teori pertanggungjawaban dapat digunakan dalam membahas terkait tanggung jawab notaris terhadap akta yang tidak dibacakannya. Berdasarkan pendapat dari Roscoe Pound, pertanggungjawaban terkait dengan suatu kewajiban untuk meminta ganti kerugian dari seseorang yang terhadapnya telah dilakukan suatu tindakan perugian atau yang merugikan (injury), baik oleh orang yang pertama itu sendiri maupun oleh sesuatu yang ada dibawah kekuasaannya. ${ }^{10}$

\section{Kewenangan Notaris}

Dalam menjalani jabatannya, notaris memiliki wewenang untuk membuat akta otentik tersebut, sebagaimana diatur dalam undang-undang Nomor 30 tahun 2004 tentang jabatan notaris. ${ }^{11}$ Undang - undang tersebut saat ini telah diubah dengan Undang Undang Nomor 2 Tahun 2014 perubahan atas Undang - Undang Nomor 30 Tahun 2004 Tentang Jabatan Notaris (UUJN-Perubahan). Notaris mendapatkan kewenangan atribusi untuk menjalankan tugas dan jabatannya. Adapun kewenangan yang dimaksud adalah sebagaimana ditentukan dalam UUJN-Perubahan, yang menentukan mengena pembuatan akta secara umum merupakan salah satu kewenangan dari jabatan notaris tersebut. Kewenangan dari notaris yang dimaksud tersebut terdiri dari: 12

a) Kewenangan Umum Notaris.

b) Kewenangan Khusus Notaris.

c) Kewenangan notaris yang akan ditentukan kemudian.

\section{Kewajiban Notaris}

Berdasarkan peraturan tentang Jabatan Notaris, seorang notaris memiliki suatu ewajiban yaitu suatu hal yang harus dilakukan oleh seorang notaris. Apabila seorang notaris tidak melakukan atau melanggar kewajiban tersebut, maka notaris tersebut

\footnotetext{
9 Op. cit. h. 5

10 Pound, Roscoe. (1996). Pengantar Filsafat Hukum (an Introduction to the Philosophy of Law) (terjemahan Mohammad Radjab). Jakarta : Bhratara. h. 80.

11 Febry, A. (2018). Kewenangan Notaris Dalam Membuat Akta Otentik Akad Pembiayaan Mudharabah Berdasarkan Hukum Islam. Repertorium, 4(1), 29-41. h. 32

12 Adjie, Habib. (2008). Hukum Notaris Indonesia. Bandung : PT. Refika Aditama. h. 78
} 
akan dikenakan sanksi atas pelanggarannya tersebut. Kewajiban notaris tersebut telah ditentukan pada Pasal 16 ayat (1)UUJN Perubahan yang mengatur tentang kewajiban notaris, diantaranya adalah membacakan Akta yang telah dibuatnya di hadapan para pihak dan juga oleh paling sedikit 2 (dua) orang saksi, atau 4 (empat) orang saksi khusus untuk pembuatan Akta wasiat di bawah tangan, dan ditandatangani pada saat itu juga oleh penghadap, saksi, dan Notaris.

\section{Larangan Notaris}

Mengenai larangan dalam jabatan notaris, telah ditentukan dalam Pasal 17 ayat (1) UUJN Perubahan diatur tentang larangan notaris yang di antaranya, Notaris dilarang menjalankan jabatannya di luar wilayah jabatannya, meninggalkan wilayah jabatannya tanpa alasan yang sah selama lebih dari 7 (tujuh) hari kerja secara berturut-turut, merangkap sebagai pegawai negeri, pejabat negara, advokat, maupun menjadi pemimpin atau pegawai badan usaha milik negara, badan usaha milik daerah atau badan usaha swasta. Notaris juga dilarang merangkap jabatan sebagai Pejabat Pembuat Akta Tanah dan/atau Pejabat Lelang Kelas II di luar tempat kedudukan Notaris dan menjadi notaris pengganti, maupun melakukan pekerjaan lain yang bertentangan dengan norma agama, kesusilaan, atau kepatutan yang dapat mempengaruhi kehormatan dan martabat jabatan notaris.

Berdasarkan uraian tersebut, pembacaan akta oleh seorang notaris tersebut adalah suatu kewajiban dalam pembentukan akta otentik tersebut. Hal ini karena dengan membacakan akta tersebut adalah salah satu bentuk dari verlijden atau peresmian dari akta otentik, selain penandatanganan akta otentik tersebut. Maka dari itu, suatu akta yang dibuat oleh notaris dalam jabatannya dan dalam lingkup wilayah kerja jabatannya tersebut, wajib dibacakan oleh notaris itu sendiri, dan tidak boleh dilakukan oleh asisten maupun pegawai notaris yang bersangkutan. Pembacaan dari akta yang dibuat oleh notaris tersebut bukan hanya bermanfaat bagi notaris, tetapi juga bagi para pihak yang menghadap. ${ }^{13}$ Pembacaan akta tersebut juga berkaitan dengan kekuatan pembuktian formil yang mana menyatakan bahwa akta notaris tersebut harus memberikan kepastian mengenai apa yang dinyatakan dan kepastian bahwa segala hal yang dicantumkan dan diuraikan dalam akta tersebut merupakan kebenaran dan sesuai dengan kehendak para pihak yang menghadap pada notaris. ${ }^{14}$ Mengenai kewajiban membacakan akta yang dibuatnya, dalam Pasal 16 ayat (7) notaris diperbolehkan untuk tidak membacakan akta yang dibuatnya, dengan suatu pengecualian untuk tidak membacakan akta yang dibuatnya apabila para penghadap menginginkan akta yang dibuat oleh notaris tersebut tidak dibacakan karena para penghadap telah membaca akta tersebut sendiri, sehingga merasa telah mengetahui dan memahami isi dari akta tersebut. Apabila akta tersebut tidak dibacakan karena pengecualian terseebut, maka ketentuan mengenai hal tersebut harus dinyatakan dalam bagian penutup akta, serta pada setiap halaman dari minuta akta diparaf oleh penghadap, para saksi dan juga Notaris. Dengan demikian dapat diartikan bahwa

${ }^{13}$ Mido, M. T. C., Nurjaya, I. N., \& Safa'at, R. (2018). Tanggung Jawab Perdata Notaris terhadap Akta yang Dibacakan oleh Staf Notaris di Hadapan Penghadap. Lentera Hukum, 5(1), 156-173. doi:10.19184/ejlh.v5i1.6288, h. 158

${ }^{14}$ Swandewi, I. A. P.(2016). Pengesahan Akta Notaris Bagi Penghadap Yang Mengalami Cacat Fisik. Acta Comitas, 29-41. doi:10.24843/ AC.2016.v01.i01.p03, h. 33 
pembacaan akta tidak wajib dilakukan selama sesuai dengan peraturan tersebut, sehingga kewajiban pembacaan akta tersebut bukan merupakan suatu keharusan.

Berbeda apabila pada penerapannya notaris secara sengaja tidak membacakan akta yang dibuat tersebut padahal notaris berada di tempat, atau akta yang dibuat tersebut tidak dibacakan karena Notaris tidak berada ditempat sehingga para penghadap dilayani oleh karyawan atau asisten Notaris, maupun akta tersebut dibacakan tetapi tidak semua yang dibacakan, dan akta dibacakan tapi bukan oleh Notaris itu sendiri, melainkan dibacakan oleh karyawan atau asisten Notaris atau penghadap tidak menghendaki akta tidak dibacakan, namun Notaris tidak menyatakan ketentuan tersebut dalam penutup akta bahwa notaris tidak membacakan akta yang dibuatnya berdasarkan kehendak para pihak. Apabila memang para pihak yang berkehendak untuk tidak dibacakan, notaris tidak boleh mencantumkan dalam bagian penutup akta bahwa notaris telah membacakan dan para penghadap telah mengerti isi dari akta tersebut. Hal ini akan berakibat pada akta yang dibuat oleh notaris tersebut tidak sesuai dengan apa yang dikehendaki oleh penghadap, atau para penghadap mungkin tidak memahami isi akta, sehingga akan menimbulkan salah pengertian dan multi tafsir mengenai isi dari akta yang dibuat notaris tersebut, akibatnya salah satu pihak dalam akta bisa melakukan wanprestasi atau akta tidak dapat dipergunakan sebagaimana mestinya.

Dalam hal demikian, apabila ternyata para penghadap melakukan wanprestasi karena tidak mengerti isi dari akta tersebut ataupun akta tersebut berbeda dengan apa yang di inginkan oleh para penghadap, maka akta tersebut tidak akan dapat berfungsi sebagaimana mestinya. Apabila terbukti notaris sengaja tidak membacakan akta tersebut maka notaris dapat dinyatakan bersalah secara administrasi dan dapat dikenakan sanksi administrasi. Disamping sanksi administrasi tersebut, notaris juga dapat dikenakan sanksi keperdataan dan sanksi dari segi pidana. ${ }^{15}$ Walaupun notaris hanya memiliki tanggung jawab atas kerugian dari para pihak sebagaimana ditentukan dalam pasal 1365 KUHPerdata, tetapi bukan berarti notaris dapat dengan bebas mengesampingkan hal tersebut. Hal ini karena ketika notaris tersebut tidak bisa membayarkan ganti kerugian materiil yang dialami para pihak dan terdapat keputusan pengadilan untuk hal ini, maka notaris tersebut dapat dinyatakan pailit oleh pengadilan. Kepailitan ini merupakan salah satu alasan yang dapat menyebabkan pemberhentian sementara notaris tersebut dari jabatannya sebagaimana ditentukan pada Pasal 9 ayat (1) huruf a UUJN-Perubahan. ${ }^{16}$

Berdasarkan Pasal 38 ayat (4) huruf a UUJN-Perubahan, bagian kepala akta dan penutup akta merupakan tanggung jawab notaris, sehingga notaris berkewajiban membacakan akta yang dibuatnya dan menulis keterangan mengenai keadaan para penghadap ketika pembuatan akta tersebut dihadapan notaris serta alasan atau keterangan mengenai akta yang tidak dibacakan oleh notaris di bagian penutup akta karena hal tersebut merupakan perintah dari Undang-undnag. Kebiasaan menyalin akta yang dilakukan notaris untuk akta yang sama dari akta yang sudah pernah dibuat

${ }^{15}$ Arifaid, P. (2017). Tanggung Jawab Hukum Notaris Terhadap Akta In Originali. Jurnal IUS Kajian Hukum dan Keadilan, 5(3), 510-520. doi:10.29303/ius.v5i3.456, h. 516

${ }^{16}$ Rahman, Y. (2017). Limitasi Pertanggungajawaban Notaris Terhadap Akta Otentik Yang Dibuatnya. Kumpulan Jurnal Mahasiswa Fakultas Hukum,1-20. h. 8 
sebelumnya, dapat menyebabkan notaris lupa mengganti bagian - bagian penting yang berhubungan dengan keadaan dari para penghadap saat pembuatan akta otentik tersebut, yang mana hal ini merupakan tanggung jawab notaris tersebut. Sehingga pada dasarnya manfaat pembacaan akta tersebut bagi Notaris merupakan suatu kontrol terhadap akta otentik yang telah dibuatnya, sehingga apabila ada kesalahan dan terjadi perubahan dari isi akta maupun yang masih salah atau isi akta belum sesuai dengan kehendak penghadap, notaris memiliki kesempatan untuk memperbaikinya. Hal ini sangat penting untuk diperhatikan, karena akibat kelalaian dan ketidak hati-hatian notaris, jika akta yang dibuat tersebut tidak sesuai dengan perintah Undang-Undang, maka akta otentik yang dibuat oleh notaris tersebut akan menjadi cacat yuridis dan menimbulkan akibat hukum terhadap pembuktian akta otentik tersebut menjadi akta yang dibuat dibawah tangan, sebagaimana ditentukan pada Pasal 16 ayat (9) UUJN-Perubahan. Akibat kesalahan tersebut tidak hanya para pihak yang mengalami kerugian, notaris sebagai pejabat yang membuat akta tersebut juga akan mengalami kerugian akibat akta yang dibuatnya bermasalah. Kerugian yang di alami notaris tersebut karena notaris akan dilaporkan kepada pihak yang berwenang dalam hal ini adalah Majelis Pengawas Daerah (MPD) Notaris, Polisi, bahkan Badan Penyelesaian Sengketa Konsumen. Tergantung dari bentuk dan besarnya kerugian yang dialami oleh para pihak akibat kesalaham dan kelalaian yang dilakukan oleh notaris dalam pembuatan akta tersebut, untuk itu notaris dapat dimintakan pertanggung jawabannya.

\subsection{Kedudukan Akta Notaris Yang Tidak Dibacakan Oleh Notaris}

Terkait dengan kedudukan akta notaris yang tidak dibacakan oleh notaris, pada dasarnya akta notaris merupakan akta otentik yang memiliki kekuatan hukum dalam hal pembuktian. Namun hal ini tidak dapat dipisahkan dari prosedur dan tata cara pembuatan akta otentik yang sesuai dengan peraturan yang berlaku. Aturan-aturan tersebut menjadi batasan bagi notaris dalam membebani atau melakukan tindakan terhadap individu. Adanya aturan itu dan pelaksanaan aturan tersebut menimbulkan kepastian hukum. ${ }^{17}$ Berdasarkan Asas Kepastian Hukum tersebut, pembuatan akta otentik yang tidak sesuai dengan ketentuan yang dimuat dalam peraturan yang berlaku, maka dapat dipertanyakan kedudukan akta tersebut. Kepastian hukum dari kedudukan akta otentik yang dibuat oleh notaris merupakan hal yang sangat penting bagi para pihak.

Sebagaimana ditentukan dalam Pasal 1868 KUHPerdata, terkait menyusun, membacakan dan menandatangani akta, Verlijden dalam proses pembuatan akta berkaitan dengan tugas dan wewenang notaris untuk membacakan akta dan memastikan bahwa akta tersebut telah dimengerti dan ditanda-tangani oleh para penghadap dan saksi - saksi yang digunakan dalam akta tersebut. Hal ini yang membedakan akta otentik notaris dengan pembuatan akta dibawah tangan. 18 Pembacaan akta tersebut adalah bagian yang penting dalam proses pembuatan akta oleh Notaris. Dengan dibacakannya akta yang dibuat oleh notaris secara langsung, maka notaris dapat mengetahui isi dan maksud dari akta tersebut agar sesuai dengan

\footnotetext{
17 Marszuki, Peter Mahmud. (2008). Pengantar Ilmu Hukum. Jakarta : Kencana. h. 58

${ }_{18}$ Multazam, M. T., \& Purwaningsih, S. B. (2018). Verlijden Pada Jabatan Notaris Di Indonesia

(Bukti Di Sidoarjo). Res Judicata, 1(1), 19-33. doi:10.29406/rj.v1i1.1036, h. 23
} 
kehendak para pihak. Selain itu, tujuan dibacakan akta tersebut oleh notaris yang bersangkutan, salah satunya adalah untuk menjamin bahwa akta yang ditandatangani adalah akta yang sama dengan yang telah dibacakan. Dengan dilakukannya pembacaan akta tersebut, merupakan sebagai kontrol bagi para pihak maupun notaris selaku pembuat akta tersebut agar mendapat kepastian bahwa akta yang dibuat merupakan kehendak para pihak yang menghadap, sehingga apabila ada hal yang dianggap salah maupun kurang, maka akta tersebut dapat diperbaiki dahulu sebelum ditandatangani oleh para penghadap, saksi - saksi, dan notaris.

Dalam menjalankan tugas dan jabatannya, notaris memiliki kewajiban untuk membacakan akta yang telah dibuatnya dihadapan para penghadap yang pada saat itu juga dihadiri oleh saksi - saksi yang dikenal notaris dan penandatanganan akta harus dilakukan setelah akta tersebut dibacakan dan disetujui para penghadap yang kemudian ditandatangani oleh para penghadap, saksi, dan Notaris. Hal tersebut sebagaimana ditentukan dalam Pasal 16 ayat (1) huruf I UUJN. Sehubungan dengan pembacaan akta ini, timbul pertanyaan, apakah akta tersebut dapat dibacakan oleh orang lain ataupun tidak dibacakan. Menurut hasil wawancara dengan notaris, dinyatakan bahwa suatu akta yang dibuat oleh notaris tersebut harus dibacakan oleh notaris itu sendiri dan tidak menyuruh pegawai maupun asisten dari notaris tersebut untuk melakukannya. Walaupun dalam praktiknya masih terdapat notaris yang secara sengaja tidak membacakan aktanya maupun akta tersebut tidak bicakan oleh notaris, melainkan pegawai atau asisten dari notaris tersebut. Hal ini harusnya mendapat perhatian lebih, karena pembacaan akta oleh Notaris merupakan bagian dari verlijden akta itu.

Melalui pembacaan akta, notaris dapat menjelaskan apa dan bagaimana isi dan maksud akta tersebut agar sesuai dengan apa yang menjadi kehendak para pihak. Setelah dilakukan pembacaan akta oleh notaris, wajib dicantumkan pada bagian akhir akta tersebut. Hal ini juga berlaku apabila para pihak tidak berkenan akta tersebut untuk dibacakan karena para penghadap telah membaca sendiri dan mengerti maksud dan tujuan dari akta yang dibuat tersebut. Untuk hal tersebut, maka notaris juga wajib mencantumkan pada bagian akhir akta yang dibuat bahwa akta tersebut tidak dibacakan karena kehendak para pihak. Hal ini sangat penting untuk dilakukan karena berkaitan dengan kedudukan dari akta yang dibuat.

Apabila notaris secara sengaja tidak membacakan akta yang dibuat tanpa persetujuan dari para penghadap, maka notaris dapat dianggap telah melakukan pelanggaran dengan tidak membacakan akta yang dibuat oleh notaris kepada para penghadap. Adapun sanksi yang dapat dikenakan sebagaimana tercantum pada Pasal 28 ayat (5) Staadblad Nomor 3 Tahun 1860 yaitu akta yang dibuat oleh notaris tersebut akan kehilangan kekuatan pembuktiannya sebagai akta otentik dan hanya akan berlaku sebagaimana akta yang dibuat dibawah tangan. Hal ini juga ditentukan dalam Pasal 84 UUJN yang pada dasarnya mengantur tentang hal yang sama, bahkan akta tersebut dianggap batal demi hukum dan dapat menjadi alasan bagi para penghadap yang merasa dirugikan untuk menuntut penggantian biaya, dan ganti kerugian kepada notaris yang bersangkutan. Berdasarkan peraturan jabatan Notaris yang baru, Notaris diharuskan membuat akta yang sesuai dengan yang ditentukan oleh peraturan perundang-undangan. Akta yang dibuat tidak sesuai dengan aturan yang berlaku karena kelalaian dalam pembuatannya oleh notaris tersebut, maka akta tersebut tidak 
memenuhi unsur akta otentik yang diatur dalam pasal 1868 KUHPerdata. Ketika akta yang dibuat oleh notaris tersebut tidak memenuhi unsur akta otentik, maka akta tersebut tidak lagi memiliki kekuatan pembuktian sebagai suatu akta otentik, dan hanya berlaku sebagai akta dibawah tangan. Pembuktian akta dibawah tangan tersebut bergantung pada pengakuan dan pernyataan dari para penghadap dan saksisaksi yang menandatangani akta tersebut, ahli warisnya serta orang-orang yang mendapat hak dari mereka.

Berdasarkan pendapat tersebut di atas, maka jelaslah bahwa sesuai dengan ketentuan Pasal 16 ayat (1) huruf 1 UUJN, akta Notaris haruslah dibacakan oleh Notaris itu sendiri tanpa diwakili oleh orang lain. Melihat ketentuan Pasal 38 ayat (4) huruf a UUJN, menentukan bahwa adanya pembacaan tersebut harus disebutkan secara tegas dalam akta Notaris. Dengan demikian, baik akta dibacakan atau tidak dibacakan harus dicantumkan pada bagian akhir akta. Jika hal itu tidak dilakukan, ada aspek formal yang tidak dipenuhi, yang mengakibatkan akta tersebut cacat hukum dan hanya mempunyai kekuatan hukum layaknya akta bawah tangan. Akta otentik yang hanya mempunyai kekuatan pembuktian di bawah tangan tersebut tidak menjadi masalah sepanjang dalam akta tersebut hanya mengatur tentang perjanjian yang disepakati oleh para pihak yang telah mengakui kebenaran semua perbuatan yang dilakukan dalam akta tersebut. Tetapi hal ini akan bermasalah ketika akta yang dibuat tersebut merupakan syarat lahirnya suatu hubungan hukum yang telah ditentukan oleh Undang - Undang, seperti pendirian Perseroan Terbatas yang mengharuskan penggunaan akta otentik. ${ }^{19}$ Dalam hal seperti itu, maka akta pendirian perseroan terbatas tersebut menjadi tidak sah karena akta pendirian tersebut menjadi bersifat sebagai akta dibawah tangan.

\section{Kesimpulan}

Notaris bertanggung jawab terhadap akta yang dibuatnya tersebut. Dalam pembuatan akta oleh notaris, pembacaan akta merupakan suatu kewajiban dalam setiap pembuatan akta otentik sebagai bagian dari verlijden atau peresmian akta (pembacaan dan penandatanganan). Akta yang dibuat oleh notaris harus dibacakan oleh notaris yang bersangkutan dan bukan oleeh pegawai atau asisten dari notaris tersebut, maupun oleh orang lain. Karena akta tersebut merupakan tanggung jawab dari notaris, sehingga ketika terjadi kesalahpahaman mengenai maksud dan isi dari akta tersebut oleh para penghadap dan mengakibatkan terjadi wanprestasi atas akta tersebut, maka notaris dianggap bertanggungjawab dan dapat dipersalahkan. Untuk itu apabila memang para penghadap tidak berkenan untuk dibacakan aktanya oleh notaris, maka notaris tetap berhak membacakan bagian kepala dan pentup dari akta yang merupakan tanggungjawabnya dan menjelaskan kepada pengahadap bahwa mereka telah mengerti dan bertanggung jawab atas akta yang telah mereka baca.

Notaris yang secara sengaja tidak membacakan akta yang dibuat dihadapan para penghadap tersebut merupakan suatu pelanggaran yang dapat mengakibatkan akta

${ }^{19}$ Kartikosari, H., \& Sesung, R. (2017). Pembatasan Jumlah Pembuatan Akta Notaris Oleh Dewan Kehormatan Pusat Ikatan Notaris Indonesia. Jurnal Panorama Hukum, 2(2), 167-184. doi:10.21067/jph.v2i2.1855, h. 180 
yang dibuatnya tersebut menjadi batal demi hukum dan kekuatan pembuktiannya menjadi sebuah akta dibawah tangan. Namun apabila para pihak yang menghadap berkehendak untuk tidak dibacakan oleh notaris, maka notaris harus mencantumkan klausula tersebut pada akhir akta bahwa para penghadap berkehendak untuk tidak dibacakan oleh notaris dan membacanya sendiri. Hal ini akan berdampak berbeda apabila tidak dicantumkannya klausula tersebut pada akhir akta ketika terjadi wanprestasi terhadap akta tersebut oleh para pihak karena ketidaktahuan mereka mengenai ketentuan yang ada pada akta tersebut dan notaris yang bertanggungjawab atas hal tersebut dan mengakibatkan akta yang dibuatnya menjadi suatu aka dibawah tangan.

\section{Daftar Pustaka}

Buku

Adjie,Habib. (2008). Hukum Notaris Indonesia. Bandung: PT. Refika Aditama.

Budiono, Herlien. (2013). Kumpulan Tulisan Hukum Perdata di Bidang Kenotariatan. Bandung : Citra Aditya Bakti.

Kie, Tan Thong. (2007). Studi Notariat \& Serba-serbi Praktek Notaris. Jakarta : Ichtiar Baru Van Hoeve.

Marszuki, Peter Mahmud. (2008). Pengantar Ilmu Hukum. Jakarta : Kencana.

Sjaifurrachman. (2011). Aspek Pertanggungjawaban Notaris dalam Pembuatan Akta. Bandung : Mandar Maju.

Soekanto, Soerjono. (2012). Pengantar Penelitian Hukum. Jakarta : UI Press.

Roscoe Pound. (1996). Pengantar Filsafat Hukum (an Introduction to the Philosophy of Law) (terjemahan Mohammad Radjab). Jakarta : Bhratara.

\section{Jurnal}

Arifaid, P. (2017). Tanggung Jawab Hukum Notaris Terhadap Akta In Originali. Jurnal IUS Kajian Hukum dan Keadilan, 5(3), 510-520. doi:10.29303/ius.v5i3.456

Darusman, Y. M. (2017). Kedudukan notaris sebagai pejabat pembuat akta otentik dan sebagai pejabat pembuat akta tanah. ADIL: Journal of Law, 7(1), 36-56

Febry, A. (2018). Kewenangan Notaris Dalam Membuat Akta Otentik Akad Pembiayaan Mudharabah Berdasarkan Hukum Islam. Repertorium, 4(1), 29-41

Kartikosari, H., \& Sesung, R. (2017). Pembatasan Jumlah Pembuatan Akta Notaris Oleh Dewan Kehormatan Pusat Ikatan Notaris Indonesia. Jurnal Panorama Hukum, 2(2), 167-184. doi:10.21067/jph.v2i2.1855

Karwelo, E. S. (2014). Prospek Pembacaan dan Penandatanganan Akta Notaris Melalui Video Conference. Kumpulan Jurnal Mahasiswa Fakultas Hukum, 1(1)

Lestari, A.D. (2014). Kekuatan Alat Bukti Akta Otentik Yang Dibuat Oleh Notaris Dalam Pembuktian Perkara Perdata Di Pengadilan Negeri Sleman. Jurnal Ilmu Hukum, 1-19.

Mido, M. T. C., Nurjaya, I. N., \& Safa'at, R. (2018). Tanggung Jawab Perdata Notaris terhadap Akta yang Dibacakan oleh Staf Notaris di Hadapan Penghadap. Lentera Hukum, 5(1), 156-173. doi:10.19184/ejlh.v5i1.6288

Multazam, M. T., \& Purwaningsih, S. B. (2018). Verlijden Pada Jabatan Notaris Di Indonesia (Bukti Di Sidoarjo). Res Judicata, 1(1), 19-33. doi:10.29406/rj.v1i1.1036

Rahman, Y. (2017). Limitasi Pertanggungajawaban Notaris Terhadap Akta Otentik Yang Dibuatnya. Kumpulan Jurnal Mahasiswa Fakultas Hukum. 1-20

Swandewi, I. A. P. Pengesahan Akta Notaris Bagi Penghadap Yang Mengalami Cacat Fisik. Acta Comitas, 29-41. doi:10.24843/AC.2016.v01.i01.p03 